\title{
Gut mucosa in the rats exposed temporary mechanical obstruction fed with probiotic
}

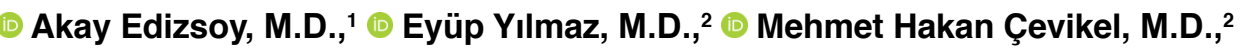

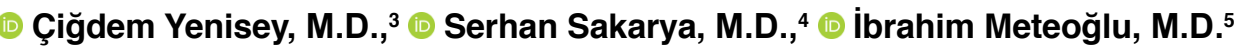

\author{
1Departmant of General Surgery, Surgical Oncology, Mersin University Faculty of Medicine, Mersin-Turkey \\ ${ }^{2}$ Departmant of General Surgery, Adnan Menderes University Faculty of Medicine, Aydın-Turkey \\ ${ }^{3}$ Departmant of Biochemistry, Adnan Menderes University Faculty of Medicine, Aydın-Turkey \\ ${ }^{4}$ Departmant of Infectious Diseases, Adnan Menderes University Faculty of Medicine, Aydın-Turkey \\ ${ }^{5}$ Departmant of Pathology, Adnan Menderes University Faculty of Medicine, Aydın-Turkey
}

\begin{abstract}
BACKGROUND: Created a model in the rats, to prevent mucosal damage and related effects in the patients, who were operated due to mechanical obstruction. Some groups fed fodder with probiotics, some groups fed with standard fodder. It is objected that the damage of gut mucosa and related effects on how to expose the differences of the groups.

METHODS: In this study, 48 female Wistar-albino type rats are separated into five groups randomly. In the first operation, rats' terminal ileum was tied up with silk except for the control group. Two groups 24 , the other two groups 48 hours later operated again and terminal ileum obstructions were removed. During that time, each one of those 24 and 48 hours of obstructed groups were fed with probiotic. Twenty-four hours later, the control group and other groups were operated for the third time for sampling. Terminal ileum, liver, spleen, MLN (Mesenteric lymph node) and blood samples were taken.
\end{abstract}

RESULTS: The research group, which was obstructed and fed with probiotics during 48 hours, was significantly observed in increased mucosa cell loss and mucosal edema. Bacterial translocation was found more common in groups without probiotics. Tissue GR (Glutathione reductase) and erythrocyte CAT (Catalase) were lower in the group of 24 hours obstructed and given probiotics.

CONCLUSION: The findings suggest that the high rate of mucosal edemas in the groups that are fed with probiotics can be seen as damage, but we think that probiotics are consonant with the strength of the mucosal barrier. Thus, in the groups fed with probiotics, it is possible that bacterial translocation is seen less, and some antioxidative enzymes are found less. Further studies are needed to investigate the benefits of probiotics in patients operated for obstruction.

Keywords: Antioxidative enzyme; bacterial translocation; mucosal damage; obstruction; probiotic.

\section{INTRODUCTION}

Mechanical ileus is an important cause of morbidity and mortality worldwide. When surgical treatment of the mechanical ileus is initiated, the obstruction disappears, but the symptoms do not regress immediately. Some complications may occur despite the operation. Perforation due to intestinal mucosal damage, bacterial translocation and sepsis are some of them, which can be life-threatening complications. In this study, our aim is to observe if there is any benefit of probiotic use in preventing or reducing complications, such as perforation, bacterial translocation and sepsis, due to intestinal mucosal damage, which may occur in the postoperative period.

The obstruction of the intestinal lumen is due to a complete or partial pathological lesion. This situation, wall, lumen inside and lumen may be due to external pressure. If there is a blockage in patients who have undergone intra-abdominal

Cite this article as: Edizsoy A, Yılmaz E, Çevikel MH, Yenisey Ç, Sakarya S, Meteoğlu İ. Gut mucosa in the rats exposed temporary mechanical obstruction fed with probiotic. Ulus Travma Acil Cerrahi Derg 2020;26:833-842.

Address for correspondence: Akay Edizsoy, M.D.

Mersin Üniversitesi Tıp Fakültesi, Genel Cerrahi Anabilim Dalı, Cerrahi Onkoloji, Mersin, Turkey

Tel: +90 324 - 24l 0000 E-mail: akayedizsoy@yahoo.com

Ulus Travma Acil Cerrahi Derg 2020;26(6):833-842 DOI: 10.14744/tjtes.2020.30269 Submitted: 30.09.2019 Accepted: I2.01.2020 Online: 21.10 .2020

Copyright 2020 Turkish Association of Trauma and Emergency Surgery 
surgery, the reason is that they are approximately $60-80 \%$ brid, 15-20\% of hernia, lumen or external tumors 15-20\% of the etiology takes place. ${ }^{[I]}$ Mechanical ileus metabolic effects occur because of fluid loss. The level and duration of obstruction are important.

The damage of the mucosa causes intestinal flora to pass into the mesenteric lymph nodes (MLN), spleen, liver and systemic circulation, which is called a bacterial translocation (BT). Local defense mechanisms provide stabilization of the intestinal flora. The first step of the barrier function is intestinal microflora. The proliferation and adhesion of pathogenic bacteria, the inhibition of bacteria in the flora, is called colonization resistance. ${ }^{[2]}$

Reduction of immune defense, hunger, burn, trauma, surgical stress, and overproliferation of intestinal flora bacteria increased permeability of intestinal mucosa, cholestasis.

BT has been shown to be associated with excessive proliferation of bacteria in the lumen of the intestine. ${ }^{[3]}$

Molecules working in advanced defense systems to prevent damage that arise from free radicals are called antioxidants. In humans, the antioxidative capacity in serum is associated with enzymatic and non-the enzymatic system. They can be endogenous and exogenous. Endogenous ones are divided into two according to whether the enzyme. Enzymes are superoxide dismutase (SOD), glutathione-S-transferases (GST), catalase (CAT), glutathione peroxidase (GSH-Px).

There are approximately 1013 cells in the human body. There are 1014 bacteria living with us in our bodies. This microbiota, which is more than the host's own cells, plays an active role at many points in the functioning of the metabolism. ${ }^{[4]}$ The most intense area is the gastrointestinal system. ${ }^{[5]}$ The microorganisms are in close contact with the intestinal mucosa of approximately $250-400 \mathrm{~m}^{2}$ area. Stomach contains 104, duodenum 103-104, jejunum 105-107, ileum 107-108, colon 1010-10II CFU/g probiotic bacteria. The mucosal defense system, which contributes to the immune system, works in conjunction with the intestinal flora. ${ }^{[6]}$

Effect mechanisms, competitive metabolic interaction with pathogens preparation of chemical products that inhibit bacteria and viruses (bacteriocins) by creating other chemicals, such as neurotransmitters, regulating other intestinal functions, such as sensitivity, susceptibility to bacterial movement (BT) inhibition in bowel wall. Mucosal barrier function enhancement mucine expression with the epithelial barrier function is the effect of cytoskeleton proteins and tight associations, such as inflammatory and immune response regulation, by indirectly affecting or indirectly causing interaction between the bacterial-mucosa and mucosal-lymphoid tissue. ${ }^{[7]}$

The mechanisms of action can be divided into two as indirect effects and directly affects:
Direct effects: Mucosal and luminal effects.

Mucosal effects: Cytokine response is on cell signal transduction and receptors.

Luminal effects: Mucus production, destruction and antagonism in the intestinal flora, competition for receptors and nutrients, butyrate production.

Indirect effects: Immunostaining, anti-infective effect, antidiarrheal effect and effects on intestinal transit.

Bifidobacterium animalis: Provides normal motility. Reduces the risk of acute diarrhea. It is used in irritable bowel syndrome. ${ }^{[8]}$

\section{MATERIALS AND METHODS}

This experimental study was conducted in Adnan Menderes University Laboratory of Experimental Animals in July 2015 with the approval of the Local Ethics Committee of Animal Experiments (64583 I0I/20I5/037). In all phases of this study, the local ethics committee's instructions dated 16 June 2009 were followed.

In this study, 48 female Wistar-albino rats weighing 200-250 grams were used in the experimental animals laboratory of Adnan Menderes University Medical Faculty. During the experiment, rats were maintained at $22 \pm 2{ }^{\circ} \mathrm{C}$ ambient temperature, I2/1 2 hours light/dark cycle, relative humidity (40-50\%) and aerated air controlled laboratory conditions. All animals were free to eat and drink water until 8-12 hours before the experiment. Before surgery, rats were kept in the laboratory for one week to get used to. Rats were fed with standard rat forage and tap water in polycarbonate transparent lattices.

Wistar-albino rats were randomly divided into five groups:

Group A: Sham group; no obstruction, only laparotomy $(n=8)$

Group B: $P(-)_{24} .24$ hours of obstruction, but not given probiotic $(n=10)$

Group C: $\mathrm{P}(-)_{48}$. 48 hours of obstruction but not given probiotic $(n=10)$

Group D: $\mathrm{P}(+)_{24} .24$ hours of obstruction and probiotic administration $(n=10)$

Group E: $\mathrm{P}(+)_{48} .48$ hours of obstruction and probiotic administration $(n=10)$

After one week of follow-up, $50 \mathrm{mg} / \mathrm{kg}$ ketamine (Alfamin ${ }^{\circledR}$; Egevet Tic. Ltd. Sti.) and $5 \mathrm{mg} / \mathrm{kg}$ xylazine (Alfazin ${ }^{\circledR}$; Egevet Tic. Ltd. Sti.) were administered intraperitoneally (Fig. Ia). After cleaning the skin of the abdomen, povidone-iodine was 

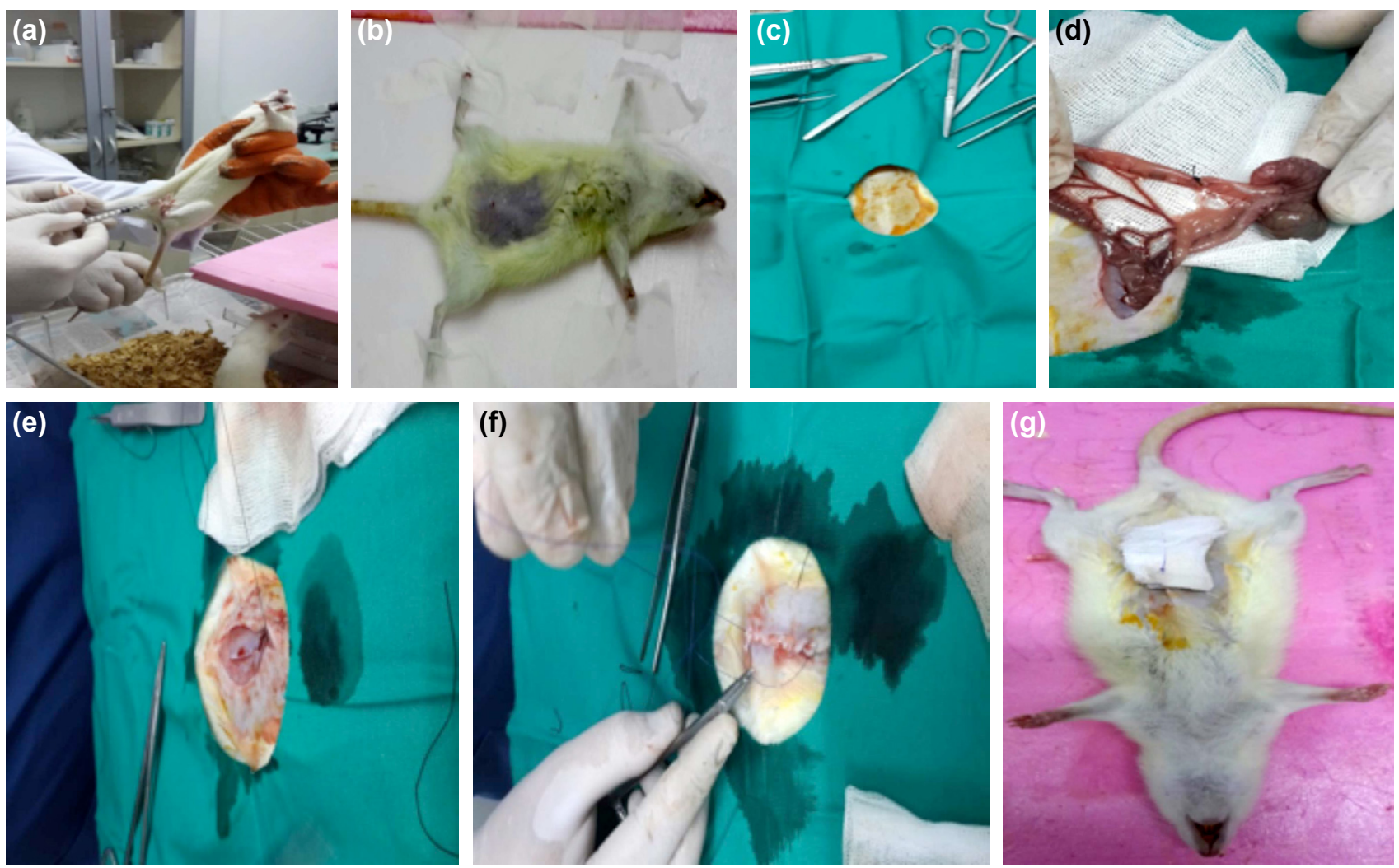

Figure 1. (a) Anesthesia, (b) shaving, (c) prepare to operation, (d) creation of mechanical obstruction, (e) abdominal closure, (f) skin closure, (g) dressing.

applied to the skin (Fig. Ib). Covered sterile and laparotomy was performed with a midline incision of approximately $3 \mathrm{~cm}$ (Fig. Ic). In groups other than group A, the ceacum was found and was ligated at $1 \mathrm{~cm}$ proximal terminal ileum, with $3 / 0$ silk (Sterisilk ${ }^{\circledR}$ ). While the ligation was performed, mechanical obstruction was formed by preventing only the passage of the bowel without causing ischemia (Fig. Id). Then, the abdomen was closed with a double layer with $4 / 0$ propyprolen (Prolene $^{\circledR}$ ) (Fig. le, f). No other procedure was performed except laparotomy and closure of the abdomen to the subjects in group A. ${ }^{[9]}$
After the operation, subjects were allowed to drink water and feed. The subjects in group $D$ and $E$ were administered either I mg/kg/day (IxI0 CFU/mg) probiotic (Bifidobacterium animalis spp lactis $B 94$, MAFLOR ${ }^{\circledR}$ ) by orogastric gavage (Fig. 2a). At the end of 24 hours, $B$ and $D$ groups were reoperated, the obstruction was removed by opening the ligation in the terminal ileum, and the subjects in group $D$ and $E$ continued to be administered the same dose of probiotic. After 48 hours, group $C$ and $E$ were reoperated, the obstruction was removed by opening the ligation in the terminal ileum, and the subjects in group $E$ continued to be administered the
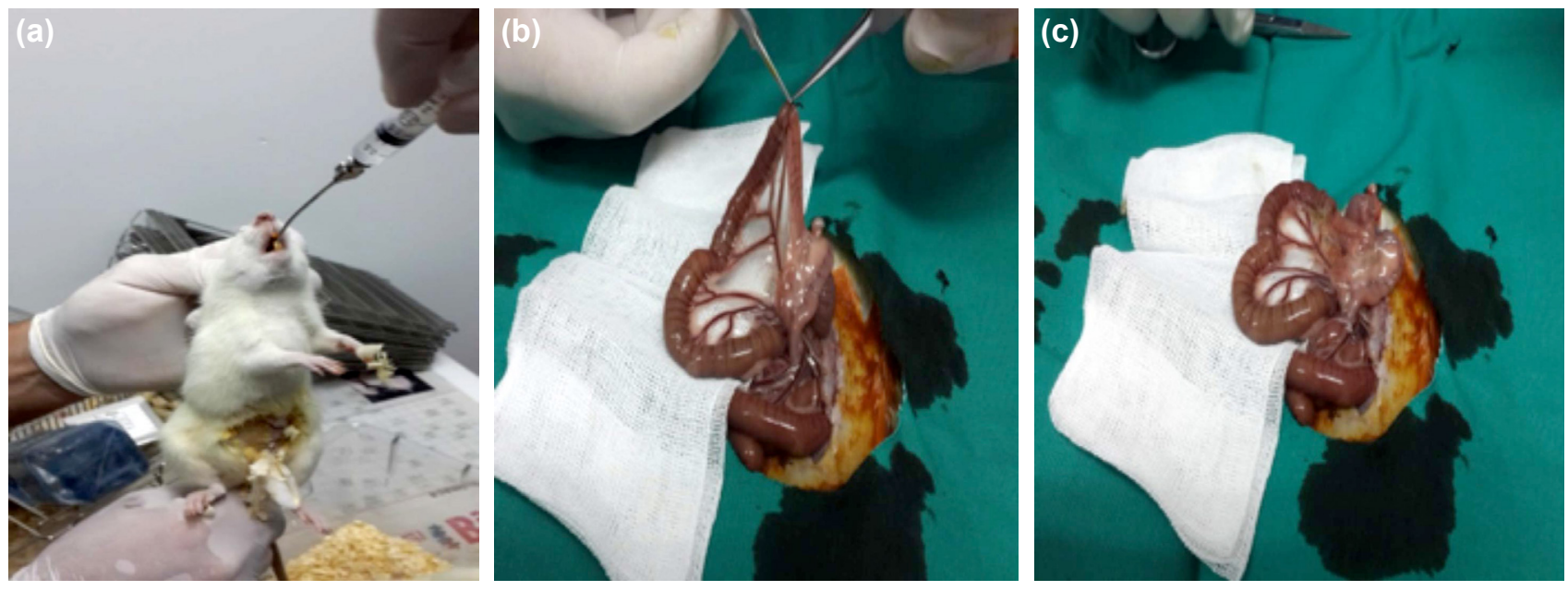

Figure 2. (a) Orogastric gavage feding, (b) remove obtruction, (c) terminal ileum after obstruction is removed. 
(a)
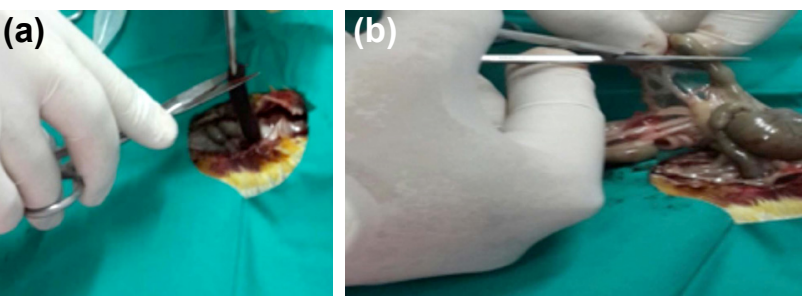

Figure 3. (a) Microbiologic sampling of spleen, (b) sampling of terminal ileum.

same dose of probiotic. Group A subjects underwent laparotomy twice, but no obstruction was performed.

It was observed that small bowel loops were dilated proximal to the obstruction before opening the ligation in the terminal ileum (Fig. 2b). One subject in group B and one subject in group $C$ were ex after the second operations.

Twenty-four hours after the second operation, all groups were operated for the third time. These operations were to obtain microbiological tissue samples from liver, spleen and mesentery, histopathological and biochemical tissue samples from the terminal ileum, biochemical samples from intracardiac blood, respectively (Fig. 3a, b). The subjects were sacrificed with cardiac collapse by intracardiac blood collection.

Terminal ileum samples were placed in sterile containers containing $10 \%$ formaldehyde. The numbers of the numbers belonged to the pathology laboratory. The liver, spleen and mesentery samples were placed in sterile falcon tubes containing $0.09 \% \mathrm{NaCl}$ and delivered to the Infectious Diseases laboratory in cold $\left(-2 l^{\circ} \mathrm{C}\right)$ storage containers. Intracardiac blood samples were placed in biochemistry tubes and transported to biochemistry laboratory in cold containers $\left(-4^{\circ} \mathrm{C}\right)$.

Some of the biochemical samples were a sample from group $\mathrm{C}$ and two from group $\mathrm{E}$, which could not be included in this study because they were inadequate.

In pathological examination, in 10\% neutral buffered formalin, $4 \mu \mathrm{m}$ thick and hematoxylin eosin dyed preparations were prepared from blocks embedded in paraffin blocks after routine tissue monitoring were examined. After staining, sections were blinded to clinical information by a single pathologist at $4,10,20$, and 40 magnifications under the light microscope (Olympus $^{\circledR}$ BX5I, Tokyo, Japan) (Fig. 4).

For evaluation, the semi-quantitative mucosal damage score, as shown by Millar et al., ${ }^{[0]}$ was performed, as shown in the table below (Table I).

Blood samples were taken into the tubes used in routine biochemistry tests and after centrifugation at 4,000 rpm for 10 minutes, each sample was separated into two Eppendorf tubes and stored in the freezer $\left(-85^{\circ} \mathrm{C}\right)$ until experiments were performed.
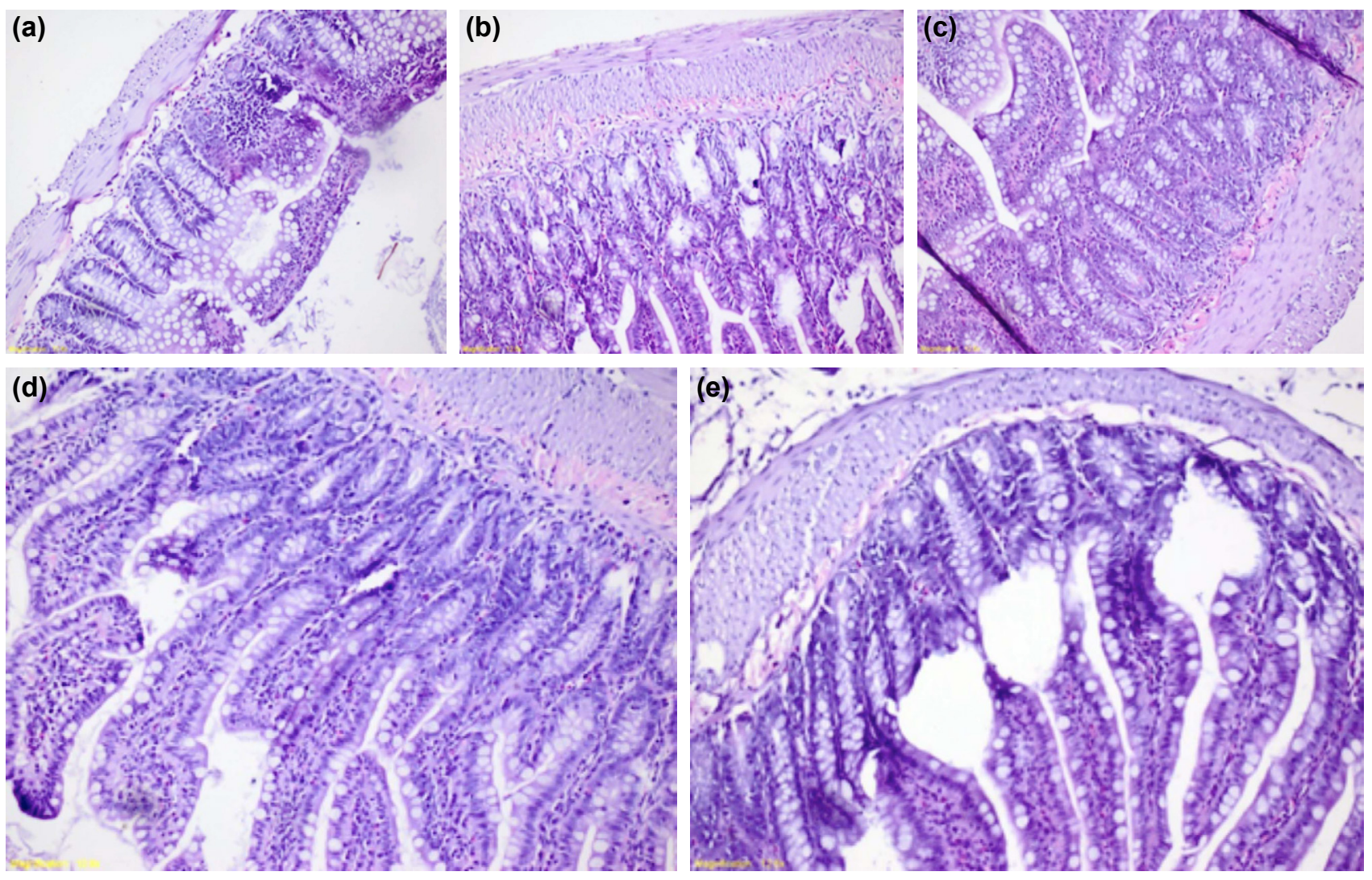

Figure 4. Terminal ileum sections from different groups. (a) Group A, (b) group B, (c) group C, (d) group D, (e) group E. 
Table I. Histopathological assessment of terminal ileum resection specimens in rats

\begin{tabular}{lc} 
Neutrophil infiltrate & \\
None 0 Slight increase I Marked increase 2 & $(0-2)$ \\
Epithelium & $(0-2)$ \\
Lamina propria & $(0-2)$ \\
Muscularis mucosa & $(0-2)$ \\
Submucosa & $(0-2)$ \\
Muscularis propria & $(0-2)$ \\
Serosa & \\
Fibrin deposition & \\
Absent 0 Present I & $(0-1)$ \\
Mucosa & $(0-1)$ \\
Submucosa & \\
Submucosal neutrophil margination & $(0-1)$ \\
Absent 0 Present I & \\
Submucosal edema & $(0-2)$ \\
Nil 0 Patchy I Confluent 2 & \\
Epithelial necrosis & $(0-1)$ \\
Nil 0 Localised I Extensive 2 & $(0-2)$ \\
Epithelial ulceration & \\
Absent 0 Present I & \\
Maximum score & \\
\hline & \\
\hline
\end{tabular}

Tissue samples were prepared as a protease inhibitor of 0.2 $\mu M$ phenylmethanesulfonyl fluoride (PMSF), I $\mu$ M Ethylenediaminetetraacetic acid (EDTA), I $\mu$ M Leupeptin containing 50 $\mu M$ phosphate buffer $(\mathrm{pH} 7.4)(\mathrm{l} / 10 \mathrm{~g} / \mathrm{ml})$ was homogenized in. The homogenates were centrifuged at $10,000 \mathrm{rpm}$ for five minutes after the sample was separated for MPO (Myeloperoxidase), and the supernatant at the top was split equally into ependorf tube and frozen at $-80{ }^{\circ} \mathrm{C}$ to allow further parameters to be checked.

The erythrocytes and supernatants obtained from tissue samples were determined using the method of Aebi et al. ${ }^{[1]}$ For CAT (Catalase), serum MDA (Malondialdehyde) was determined using Ohkowa's method. ${ }^{[12]}$ Results were given as $\mu$ M. MDA values in tissue samples Konukoglu et al. ${ }^{[13]}$ It was measured in whole blood and tissue supernatant according to Tietze's method for GSH (Glutathione). ${ }^{[14]}$ GPx (Glutathione peroxidase) activity in erythrocytes measured according to the method of Pleban et al. ${ }^{[15]}$ GPx activity in tissue supernatant was determined using Kakkar et al.'s ${ }^{[16]}$ method by minor modification. GR (Glutathione reductase) activity in erythrocytes and tissue was determined using the method of Racker et al. ${ }^{[17]}$ The measurement of SOD (Superoxide dismutase) in erythrocytes and tissue supernatants was determined according to the method of Sun et al. ${ }^{[8]} \mathrm{NO}$ (Nitric oxide) levels in serum, and tissue supernatant were determined according to the method of Navarro-Gonzálvez et al. ${ }^{[19]}$

Under the sterile conditions, liver, spleen, and mesenteric lymph node specimens were previously placed in a $15 \mathrm{cc}$ sterile falcon tubes each with sterile 2 cc $0.09 \% \mathrm{NaCl}$ (Sodium chloride) added and numbered without group information. The groups to which the numbers belong were also recorded. The tubes were then homogenized by sonication.

From the homogenized samples, I cc of the homogenized samples was taken into 2 cc Eppendorf tubes and then stored at $-20^{\circ} \mathrm{C}$ to measure the amount of protein they contained. After sowing culture containers were recorded with numbersof sample and incubated at $37^{\circ} \mathrm{C}$ for 24 hours. At the end of 24 hours, bacteria colonies were counted (Fig. 5).

Frozen samples created by sonicator (Fig. 6a) in Eppendorf tubes were kept at $37^{\circ} \mathrm{C}$ for 30 minutes. The tubes were then centrifuged at $13300 \mathrm{rpm}$ for five minutes. Protein measurement was performed using Bicinchoninic acid assay (BCA) method, as shown by Smith et al. ${ }^{[20]}$ All samples were placed in the wells to be used in the spectrophotometer, including blind samples for the first row reset, and incubated at $37^{\circ} \mathrm{C}$ for 30 minutes (Fig. 6b, c). The results obtained in the spectrophotometer were then proportional to the number of colonies. These ratios were recorded as colony/l mg protein for statistical purposes.

\section{RESULTS}

The appropriateness of the quantitative data to the normal distribution was investigated using Kolmogorov Smirnov test.
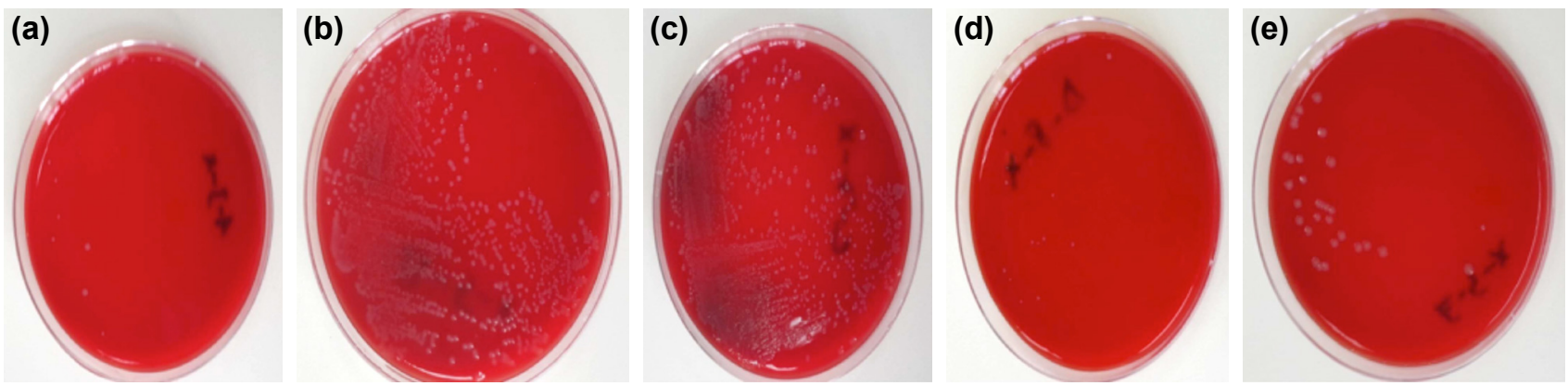

Figure 5. Colonies from liver samples. (a) Group A, (b) Group B, (c) Group C, (d) Group D, (e) Group E. 

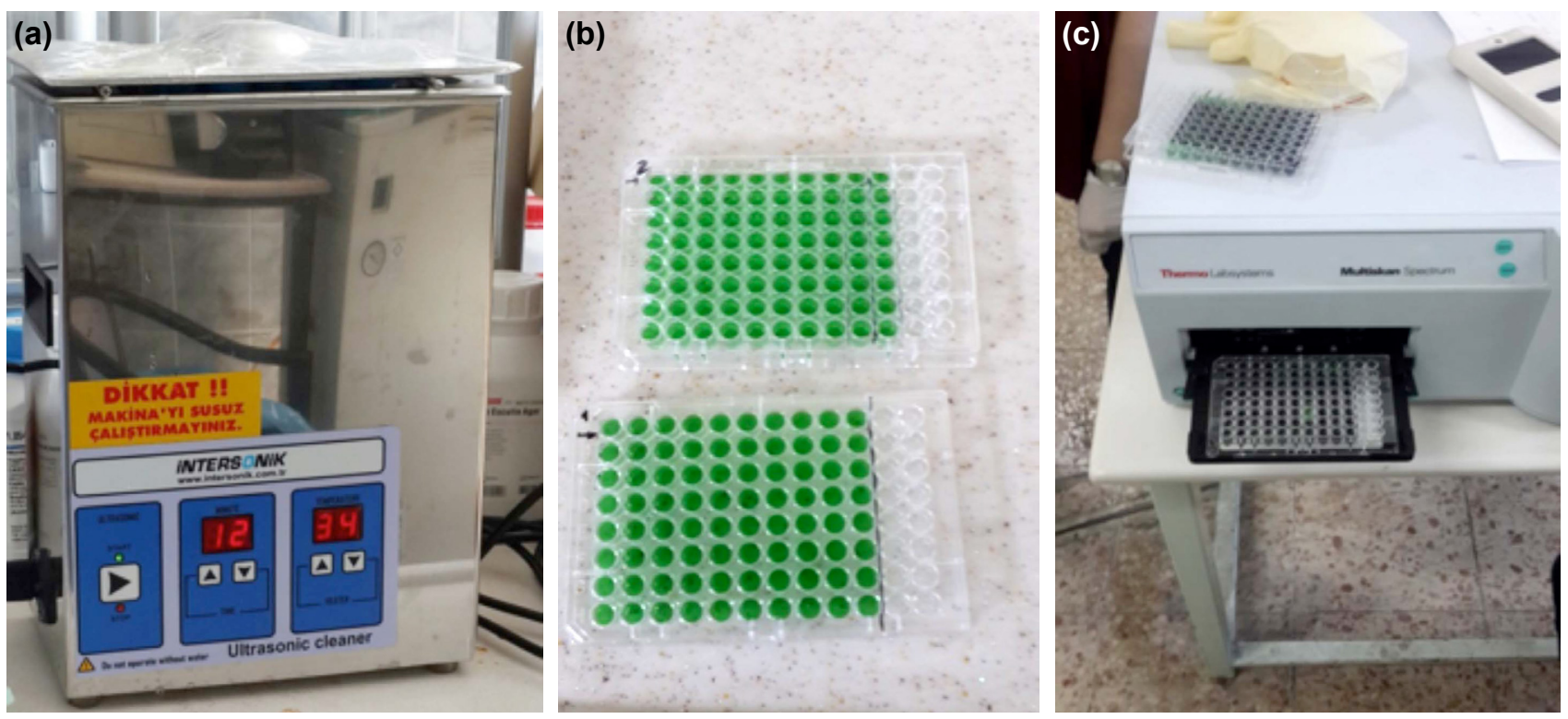

Figure 6. (a) Sonicator, (b) samples in wells, (c) spectrophotometer.

One-way analysis of variance (ANOVA) was used in statistical comparisons for the variables which were suitable for normal distribution and descriptive statistics were shown as mean \pm standard deviation. The Kruskal-Wallis test was used for statistical comparisons for variables not suitable for normal distribution and descriptive statistics were shown in the form of median (25-75 percentile). $\mathrm{P}<0.05$ was considered statistically significant.

During the experiment, two subjects from the $C$ group could not be included in the statistical studies due to inadequate sampling for only biochemical test. A subject from the $E$ group and a subject from the $C$ group died after the second operation. Thus, they were excluded from statistical studies.

There were significant differences in mucosal damage scores between groups. Mucosal damage scores was lower in group A than in group $E(p=0.023)$ (Table 2).
In microbiological variables, the difference in bacterial colonization rates of liver, spleen and mesentery was observed (Table 3). In the liver, bacteria were more colonized in group $B$ than in group $D(p<0.001)$. Test results showed that the bacteria colonized in group $C$ were more than group $A$ and $E$ (Table 3), (Fig. 7). In the spleen colonized by bacteria in group $B$ was more than group D $(p<0.001)$ (Fig. 8). According to this, the maximum BT was seen in the group with 48 hours obstructed and not given probiotic (group C), while the least it was observed in the group with 24 hours obstructed and given probiotic (group B).

Biochemically, some differences were detected in tissue, serum and whole blood samples (Table 4). NO levels in group A were found to be higher than $B, D$ and $E$ groups $(p<0.05)$ (Fig. 9). When erythrocyte catalase levels were measured in whole blood samples, group $D$ groups were found to be less than groups $A$ and $B(p<0.005)$ (Fig. 10).

Table 2. Anova test results applied to mucosal damage scores

\begin{tabular}{|c|c|c|c|c|c|c|}
\hline Group & A & B & C & D & $\mathbf{E}$ & $\mathbf{P}$ \\
\hline Score & $3.7500 \pm 1.58 \mid 14$ & $4.0000 \pm 1.73205$ & $4.1111 \pm 1.76383$ & $5.5000 \pm 1.26930$ & $6.0000^{\alpha} \pm 0.70711$ & 0.023 \\
\hline
\end{tabular}

$\alpha$ : Group E differed from groups A.

Table 3. Kruskal Wallis test results applied to bacterial translocation parameters

\begin{tabular}{lcccccc}
\hline Group & A & B & C & D & E & P \\
\hline Liver & 145.26 & $979.94^{\alpha}$ & $1685.65^{\beta}$ & 32.65 & 29.29 & $<0.001$ \\
Spleen & 76.255 & 1126.03 & 2166.4 & $3.155^{\gamma}$ & 41.29 & $<0.001$ \\
Mesentery & 128.775 & 177.56 & 550.47 & 31.16 & 85.93 & 0.028 \\
\hline
\end{tabular}

$\alpha$ : Group B differed from groups D. $(B>D) ; \beta$ : Group $C$ differed from groups $A$ and $E$. $(C>A>E)$; $\gamma$ : Group $D$ differed from groups $B$. (B>D). 


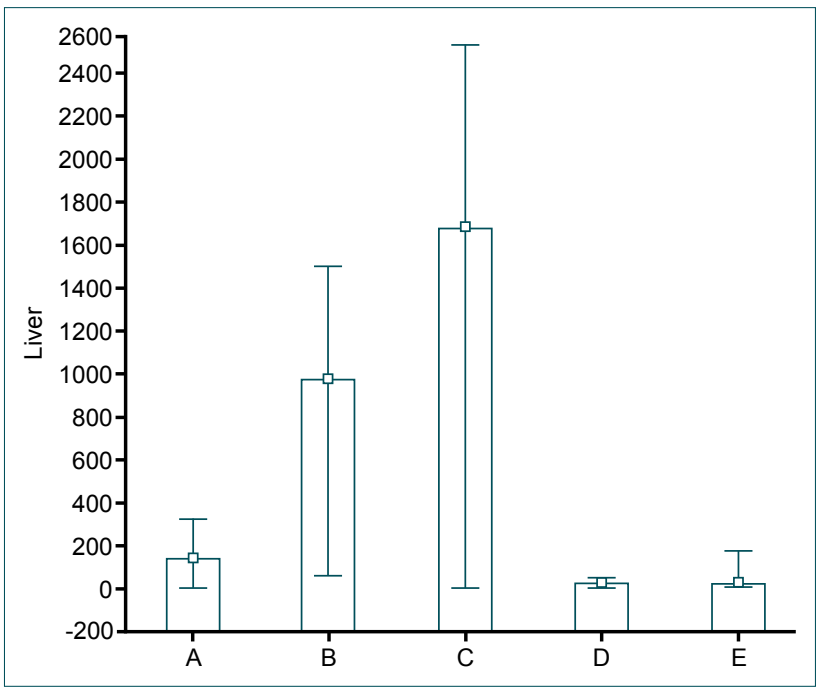

Figure 7. Median distribution of bacterial translocation rates to the liver (colony/1 mg protein). Group B differed from $D$ and $E$ groups. Group C differed from groups A, D and E $(p<0.005)$.

The differences between the groups in terms of Tissue GSH, Tissue SOD and Erythrocyte GR were not significant (Table 5).

\section{DISCUSSION}

The groups were given short names $\left[\mathrm{B}: \mathrm{P}(-)_{24}, \mathrm{C}: \mathrm{P}(-)_{48}, \mathrm{D}: \mathrm{P}\right.$ $(+)_{24}$, E: $\mathrm{P}(+)_{48}$ ] according to probiotic administration and occlusion time. The samples were taken in the third operation.

Lu et al. ${ }^{[21]}$ studied the contribution of SOD to the development of ileal obstruction in rats and healing of mucosal damage. It was shown that the mucosal damage score increased in the groups with 24 hours of obstruction compared to the control group. In our study, it was shown that mucosal damage was higher in the obstruction group compared to the control group. However, mucosal damage score in the $\mathrm{P}(+)_{48}$ group was higher than in the control group. There was no significant difference in mucosal damage between the groups who had 24 or 48 hour obstruction with or without probiotic administration.

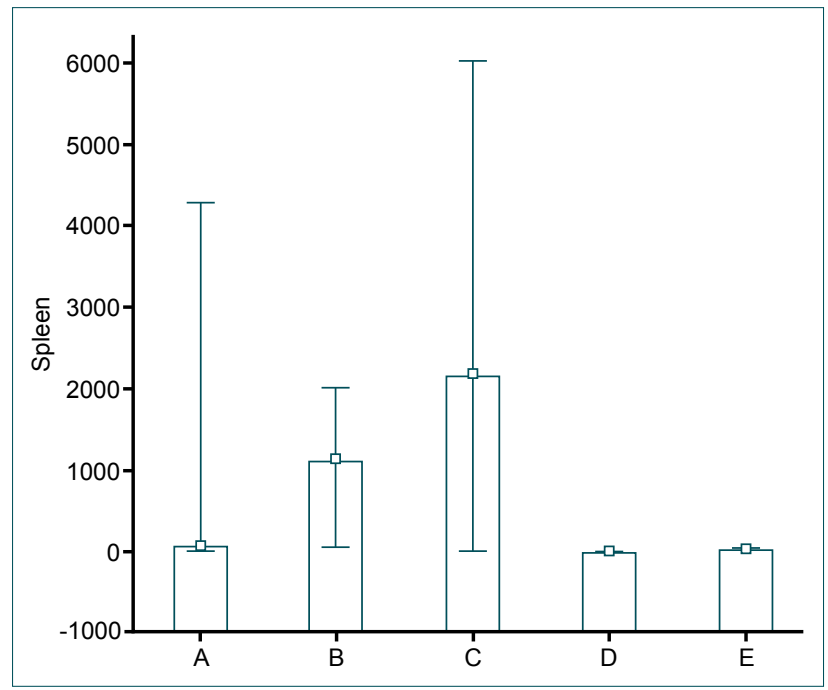

Figure 8. Median distribution of bacterial translocation rates to the spleen (colony $/ 1 \mathrm{mg}$ protein). $\mathrm{D}$ group differed from $\mathrm{B}$ and $\mathrm{C}$ groups $(p<0.05)$.

In a study that examined the effects of probiotic nutrition in rats with radiation-induced mucosal damage, no difference was detected between the group given to the probiotic group and the control group and bacterial translocation to the liver, spleen and mesenteric lymph nodes separately. ${ }^{[22]}$ In our study, mucosal damage was achieved by obstruction of 24 or 48 hours. The rate of bacterial colony in the liver was higher in the non-probiotic groups. The colonization rate in spleen samples from $\mathrm{P}(+)_{24}$ group was less than in $\mathrm{P}(-)_{24}$ group.

El-Awady et al. ${ }^{[23]}$ performed a 28-hour study of rats with ileal obstruction and strangulated obstruction. In simple obstruction, tissue GPx and tissue MDA oxidative stress parameters were elevated. In our study, $\mathrm{NO}$ levels were higher in the control group than in the $\mathrm{P}(-)_{24}, \mathrm{P}(+)_{24}$ and $\mathrm{P}(+)_{48}$ groups.

When erythrocyte catalase levels were measured, $\mathrm{P}(+)_{24}$ was found to be less than $\mathrm{P}(-)_{24}$ and control group.

Table 4. Kruskal Wallis test results applied to biochemical parameters

\begin{tabular}{|c|c|c|c|c|c|c|}
\hline Group & A & B & C & D & $\mathbf{E}$ & $\mathbf{P}$ \\
\hline Tissue GR & 1012.5 & 797.872 & 1125 & 150 & 600 & 0.025 \\
\hline Tissue NO & 1.068706 & 0.793412 & 0.8287055 & 0.962824 & 0.736941 & 0.328 \\
\hline Serum MDA & 149.167 & 207.5 & 170.833 & 182.5 & 136.667 & 0.94 \\
\hline Serum NO & $39.412^{\alpha}$ & 14.018 & 23.655 & 11.3515 & 16.4425 & $<0.05$ \\
\hline Erythrocyte SOD & 177.477 & 181.745 & 186.04 & 200.052 & 198.486 & 0.324 \\
\hline Erythrocyte CAT & 634.4115 & 718.46 & 569.126 & $420.161^{\beta}$ & 482.69 & $<0.05$ \\
\hline Erythrocyte GSH & 21.719 & 20.391 & 20.25 & 21.875 & 19.688 & 0.474 \\
\hline
\end{tabular}

$\alpha$ : Group A differed from groups B, D and E; $\beta$ : Group D differed from groups A and B.

GR: Glutathione reductase; NO: Nitric oxide; MDA: Malondialdehyde; SOD: Superoxide dismutase; CAT: Catalase; GSH: Glutathione. 


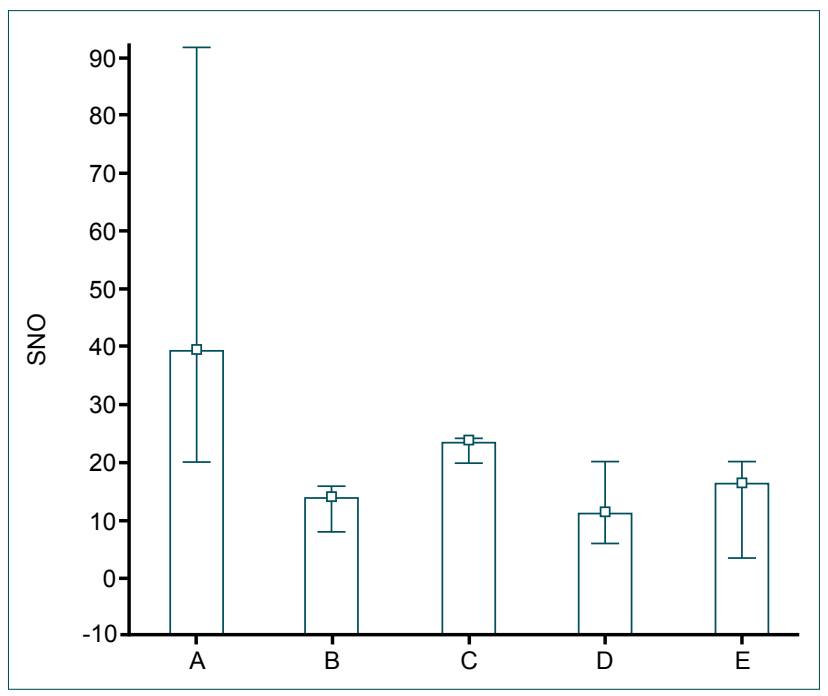

Figure 9. Median distribution of nitric oxide values measured in serum samples. Group A differed from B, D and E groups $(p<0.005)$.

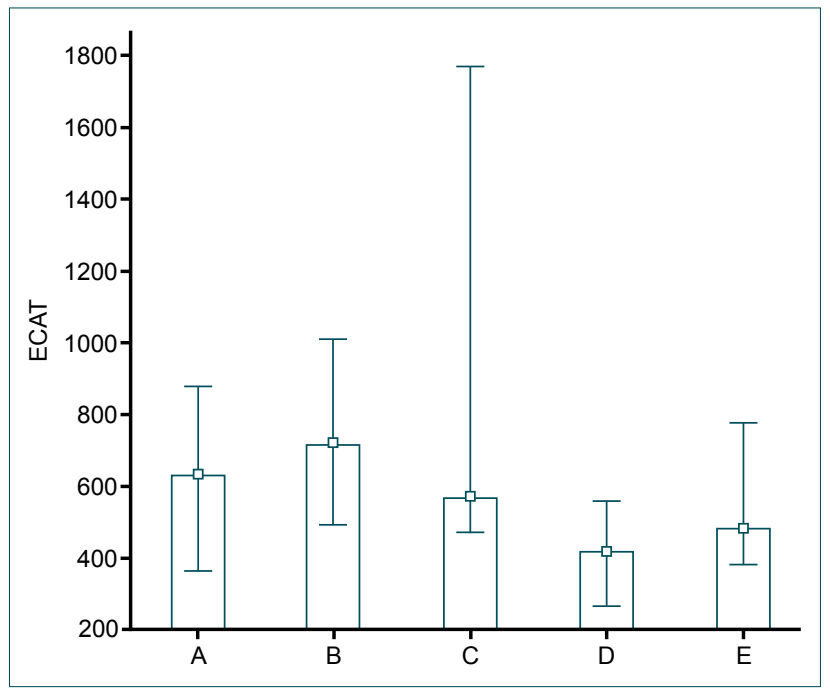

Figure 10. Median distribution of catalase values measured in erythrocyte extracted samples. D group differed from A, B and C groups $(p<0.005)$.

Aldemir et al. ${ }^{[24]}$ administered intravenous octreotide acetate or a probiotic S. boulardii orogastric in rats treated with ileal loop obstruction, and bacterial translocation and villous width values were measured. S. boulardii and octreotide acetate groups were shown to be more villous and less bacterial translocation than untreated group. In our study, Bifidobacterium animalis spp lactis B94 was used as probiotic. In our study, vascular enlargement was evaluated as mucosal edema and an increase was observed in probiotic groups. Bacterial translocation was found to be decreased in the probiotic group.

In our study, we showed a decrease in bacterial translocation in the groups in which we used Bifidobacterium animalis spp lactide B94. Similarly, Generoso et al. ${ }^{[25]}$ showed differences using the Saccharomyces cerevisiae strain UFMG 905. In the

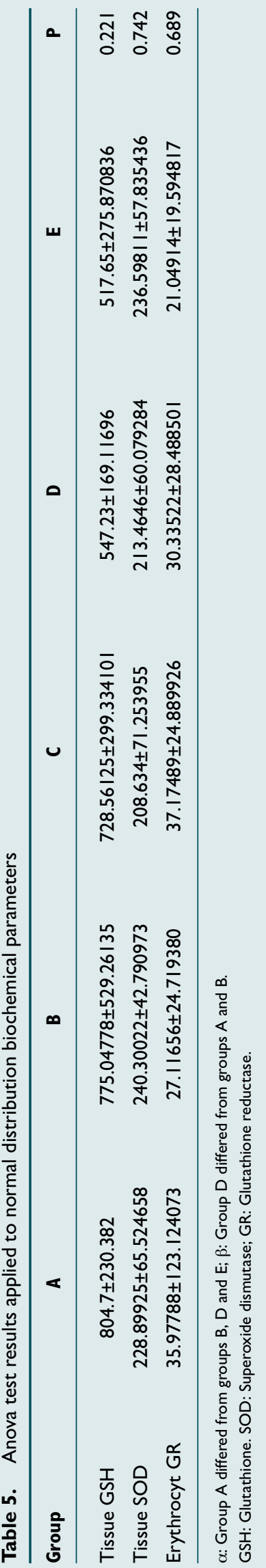


same study, mucosal edema was detected histopathologically in the probiotic groups. In our study, mucosal edema increased in $\mathrm{P}(+)_{48}$ group compared to control group.

In their study, Antequera et al. ${ }^{[26]}$ compared bacterial translocation and mucosal damage at $24,48,72$ hours in experimental rats with experimental intestinal obstruction. In the first 24 hours, they did not detect any significant change in mucosa epithelium. They showed a significant increase in vascular dilatation and mucosal edema after 48 hours. In our study, mucosal edema was found more in group $\mathrm{P}(+)_{48}$ than control group $(p<0.05)$. This may be because probiotics increase mucosal edema.

Mañé et al. ${ }^{[27]}$ produced colitis in rats and gave them different probiotics. Samples were taken after I-3 weeks. In this study, mucosal damage was found to be less in probiotic groups. We thought that following mechanical obstruction of rats for seven days would result in high mortality. In addition, since we tried to mimic the patient model whose mechanical obstruction was treated with surgery, the samples were taken in the early period. Therefore, differences between the groups may be restricted. Also, we think that the probiotic narrows the gap between cells with edema and thus inhibits bacterial transfer.

Cardiopulmonary bypass causes intestinal mucosa damage and bacterial translocation. Ying-Jie Sun et al. ${ }^{[28]}$ gave probiotic mixture to a group of rats where they applied cardiopulmonary bypass. Bacterial translocation to the liver and mesentery was more common in the probiotic group. In our study, BT to liver was lower in $\mathrm{P}(+)_{24}$ group than $\mathrm{P}(-)_{24}$ group, at $\mathrm{P}(+)_{48}$, less than $\mathrm{P}(-)_{48}$.

When evaluating mucosal damage, in Chiu scoring,, ${ }^{[29]}$ the vascular congestion parameter corresponds to the edema parameter in the scoring we used in our study. In Lutgendorff et al.'s ${ }^{[30]}$ study evaluating intestinal mucosal injury in rats, which produced pancreatitis using glycodeoxycholic acid, gave a group a mixture of Lactobacillus acidophilus, Lactobacillus casei, Lactobacillus salivarius, Lactococcus lactis, Bifidobacterium bifidum and Bifidobacterium lactis, Chiu scoring and the probiotic group, they found less mucosal damage than the group not given. In the probiotic group, an increase and enlargement of the epithelium corresponding to edema was detected, but the structure of the epithelium was intact. Our study showed a significant correlation and edema that was significantly higher in the probiotic group. However, no difference was found in other parameters. Lutgendorff et al. observed a significant difference in tissue GSH values in the probiotic group in the same study. In our study, there was no significant difference between the groups concerning GSH values obtained from tissue and erythrocyte.

\section{Conclusion}

In this study, we found that probiotics did not reduce the occlusion-induced mucosal damage in the first 48 hours. We have shown a reduction in bacterial translocation. We even showed increased mucosal edema. We think that probiotics may have obstacle on BT, so this may have a decreasing effect on the morbidity and mortality caused by BT. In addition, in our study, the findings suggest that probiotics support antioxidant defense. As a result, it is possible to obtain positive results with the widespread use of probiotics in surgery. However, our study is a preliminary, experimental study. For their effects on humans, more detailed clinical studies are needed.

Ethics Committee Approval: Adnan Menderes University Animal Experiments Local Ethics Committee granted approval for this study (date: 27.04.2015, number: 64583 I0I/2015/37).

Peer-review: Internally peer-reviewed.

Authorship Contributions: Concept: A.E.; Design: A.E.; Supervision: M.H.Ç., M.Y.; Resource: A.D.U., B.A.P.; Materials: A.D.U., D.H.L.; Data: Ç.Y.; Analysis: S.S., I.M.; Literature search: A.E., M.Y., Ç.Y.; Writing: A.E.; Critical revision: M.H.Ç.

Conflict of Interest: The authors declare that have no conflict of interest.

Financial Disclosure: The authors declared that this study has received financial support by Adnan Menderes University Scientific Research projects.

\section{REFERENCES}

1. Welch JP. General consideration and mortality in bowel obstruction. In: Welch JP, editor. Bowel obstruction: differential diagnosis and clinical management. Philadelphia: Saunders;1990.p.59-95.

2. van der Waaij D, Berghuis-de Vries JM, Lekkerkerk Lekkerkerk-v. Colonization resistance of the digestive tract in conventional and antibiotic-treated mice. J Hyg (Lond) 1971;69:405-11. [CrossRef]

3. Guarner C, Runyon BA, Young S, Heck M, Sheikh MY. Intestinal bacterial overgrowth and bacterial translocation in cirrhotic rats with ascites. J Hepatol 1997;26:1372-8. [CrossRef]

4. Clemente JC, Ursell LK, Parfrey LW, Knight R. The impact of the gut microbiota on human health: an integrative view. Cell 2012;148:1258-70.

5. Gerritsen J, Smidt H, Rijkers GT, de Vos WM. Intestinal microbiota in human health and disease: the impact of probiotics. Genes Nutr 2011;6:209-40. [CrossRef]

6. Thomas DW, Greer FR; American Academy of Pediatrics Committee on Nutrition; American Academy of Pediatrics Section on Gastroenterology, Hepatology, and Nutrition. Probiotics and prebiotics in pediatrics. Pediatrics 2010;126:1217-31. [CrossRef]

7. Chmielewska A, Szajewska H. Systematic review of randomised controlled trials: probiotics for functional constipation. World J Gastroenterol 2010;16:69-75.

8. Deshpande G, Rao S, Patole S. Progress in the field probiotics: year 2011. Curr Opin Gastroenterol 2011;27:13-8. [CrossRef]

9. Quirino IE, Correia MI, Cardoso VN. The impact of arginine on bacterial translocation in an intestinal obstruction model in rats. Clin Nutr 2007;26:335-40. [CrossRef]

10. Millar AD, Rampton DS, Chander CL, Claxson AW, Blades S, Coumbe $\mathrm{A}$, et al. Evaluating the antioxidant potential of new treatments for inflammatory bowel disease using a rat model of colitis. Gut 1996;39:407-15.

11. Aebi H. Catalase. In: Bergmeyer HU, editor. Methods of Enzymatic Analysis. Weinheim, NewYork: Verlag Chemie \& Academic Press In- 
c;1974.p.673-80. [CrossRef]

12. Ohkawa $\mathrm{H}$, Ohishi N, Yagi K. Assay for lipid peroxides in animal tissues by thiobarbituric acid reaction. Anal Biochem 1979;95:351-8. [CrossRef]

13. Konukoglu D, Iynem H, Ziylan E. Antioxidant status in experimental peritonitis: effects of alpha tocopherol and taurolin. Pharmacol Res 1999;39:247-51. [CrossRef]

14. Tietze F. Enzymic method for quantitative determination of nanogram amounts of total and oxidized glutathione: applications to mammalian blood and other tissues. Anal Biochem 1969;27:502-22. [CrossRef]

15. Pleban PA, Munyani A, Beachum J. Determination of selenium concentration and glutathione peroxidase activity in plasma and erythrocytes. Clin Chem 1982;28:311-6. [CrossRef]

16. Kakkar R, Mantha SV, Radhi J, Prasad K, Kalra J. Increased oxidative stress in rat liver and pancreas during progression of streptozotocin-induced diabetes. Clin Sci (Lond) 1998;94:623-32. [CrossRef]

17. Racker E. Glutathione reductase (liver and yeast) In: Colowick SP, Kaplan NO, editors. Methods in Enzymology. Vol. 2. New York, NY, USA: Academic Press; 1955.p.722-9. [CrossRef]

18. Sun Y, Oberley LW, Li Y. A simple method for clinical assay of superoxide dismutase. Clin Chem 1988;34:497-500. [CrossRef]

19. Navarro-Gonzálvez JA, García-Benayas C, Arenas J. Semiautomated measurement of nitrate in biological fluids. Clin Chem 1998;44:679-81.

20. Smith PK, Krohn RI, Hermanson GT, Mallia AK, Gartner FH, Provenzano MD, et al. Measurement of protein using bicinchoninic acid. Anal Biochem 1985;150:76-85. [CrossRef]

21. Lu RH, Chang TM, Yen MH, Tsai LM. Involvement of Superoxide Anion in the Pathogenesis of Simple Mechanical Intestinal Obstructi Involvement of superoxide anion in the pathogenesis of simple mechanical intestinal obstruction. J Surg Research 2003;115:184-90. [CrossRef]

22. Demirer S, Aydintug S, Aslim B, Kepenekci I, Sengül N, Evirgen O, et al.
Effects of probiotics on radiation-induced intestinal injury in rats. Nutrition 2006;22:179-86. [CrossRef]

23. El-Awady SI, El-Nagar M, El-Dakar M, Ragab M, Elnady G. Bacterial translocation in an experimental intestinal obstruction model C-reactiveprotein reliability?. Acta Cirúrgica Brasileira 2009;24:98-106. [CrossRef]

24. Aldemir M, Kökoğlu OF, Geyik MF, Büyükbayram H. Effects of octreotide acetate and Saccharomyces boulardii on bacterial translocation in an experimental intestinal loop obstruction model of rats. Tohoku J Exp Med 2002;198:1-9. [CrossRef]

25. Generoso SV, Viana M, Santos R, Martins FS, Machado JA, Arantes RM, et al. Saccharomyces cerevisiae strain UFMG 905 protects against bacterial translocation, preserves gut barrier integrity and stimulates the immune system in a murine intestinal obstruction model. Arch Microbiol 2010;192:477-84. [CrossRef]

26. Antequera R, Bretaña A, Cirac A, Brito A, Romera MA, Zapata R. Disruption of the intestinal barrier and bacterial translocation in an experimental model of intestinal obstruction. Acta Cientifica Venezola 2000;51:18-26.

27. Mañé J, Lorén V, Pedrosa E, Ojanguren I, Xaus J, Cabré E, et al. Lactobacillus fermentum CECT 5716 prevents and reverts intestinal damage on TNBS-induced colitis in mice. Inflamm Bowel Dis 2009;15:1155-63.

28. Sun YJ, Cao HJ, Song DD, Diao YG, Zhou J, Zhang TZ. Probiotics can alleviate cardiopulmonary bypass-induced intestinal mucosa damage in rats. Dig Dis Sci 2013;58:1528-36. [CrossRef]

29. Chiu CJ, McArdle AH, Brown R, Scott HJ, Gurd FN. Intestinal mucosal lesion in low-flow states. I. A morphological, hemodynamic, and metabolic reappraisal. Arch Surg 1970;101:478-83. [CrossRef]

30. Lutgendorff F, Nijmeijer RM, Sandström PA, Trulsson LM, Magnusson KE, Timmerman HM, et al. Probiotics prevent intestinal barrier dysfunction in acute pancreatitis in rats via induction of ileal mucosal glutathione biosynthesis. PLoS One 2009;4:e4512. [CrossRef]

\title{
DENEYSEL ÇALIŞMA - ÖZET
}

\section{Geçici mekanik obstrüksiyona maruz kalmış, probiyotik ile beslenen sıçanlarda bağırsak mukozası}

\section{Dr. Akay Edizsoy, ${ }^{1}$ Dr. Eyüp Yılmaz, ${ }^{2}$ Dr. Mehmet Hakan Çevikel, ${ }^{2}$ Dr. Çiğdem Yenisey, ${ }^{3}$ Dr. Serhan Sakarya, ${ }^{4}$ İbrahim Meteoğlu ${ }^{5}$}

\begin{abstract}
${ }^{1}$ Mersin Üniversitesi Tıp Fakültesi, Genel Cerrahi Anabilim Dalı, Cerrahi Onkoloji, Mersin
${ }^{2}$ Adnan Menderes Üniversitesi Tıp Fakültesi, Genel Cerrahi Anabilim Dalı, Aydın

${ }^{3}$ Adnan Menderes Üniversitesi Tıp Fakültesi, Tıbbi Biyokimya Anabilim Dalı, Aydın

${ }^{4}$ Adnan Menderes Üniversitesi Tıp Fakültesi, Enfeksiyon Hastalıkları Anabilim Dalı, Aydın

${ }^{5}$ Adnan Menderes Üniversitesi Tıp Fakültesi, Pataloji Anabilim Dalı, Aydın
\end{abstract}

AMAÇ: Mekanik obstrüksiyon nedeniyle ameliyat edilen hastalarda mukozal hasarı ve buna bağlı etkileri önlemek için sıçanlarda bir model oluşturuldu. Bazı gruplara yemleri ile probiyotik verilerek, bazıları ise standart yemlerle beslendi. Bağırsak mukozasının zarar görmesi ve buna bağlı olan etkilerin gruplar arasında farklılık ortaya çıkarması beklendi.

GEREÇ VE YÖNTEM: Kırk sekiz dişi wistar-albino tipi sıçan rastgele beş gruba ayrıldı. İlk operasyonda, kontrol grubu dışındaki sıçanların bağırsakları terminal ileum düzeyinde ipek ile bağlandı. İki grup 24, diğer iki grup 48 saat sonra tekrar ameliyat edildi ve terminal ileumdaki obtrüksiyonları kaldırıldı. Bu süre zarfında, 24 ve 48 saat obstrükte kalan gruplardan her birine probiyotik verildi. Yirmi dört saat sonra, kontrol grubu ve diğer gruplar örnekleme için üçüncü kez ameliyat edildi. Terminal ileum, karaciğer, dalak, MLN (mezenterik lenf nodu) ve kan örnekleri alındı.

BULGULAR: Kırk sekiz saat boyunca obstrükte kalan ve probiyotiklerle beslenen araştırma grubunda mukozal hücre kaybı ve mukozal ödemde belirgin olarak artış gözlendi. Bakteriyel translokasyon, probiyotik verilmeyen gruplarda daha yaygın bulundu. Doku GR (Glutatyon redüktaz) ve eritrosit CAT (katalaz), 24 saat boyunca tıkalı ve probiyotik verilen grupta daha düşüktü.

TARTIŞMA: Probiyotiklerle beslenen gruplardaki yüksek mukozal ödem oranları hasar olarak görülebilir, ancak probiyotiklerin mukozal bariyer etkisi ile uyumlu olduğunu düşünüyoruz. Böylece probiyotiklerle beslenen gruplarda, bakteriyel translokasyonun daha az görülmesi ve bazı antioksidan enzimlerin daha düşük bulunması mümkündür. Probiyotiklerin cerrahi hastalarda yararlarını belirlemek için ileri çalışmalara ihtiyaç vardır. Anahtar sözcükler: Antioksidan enzim; bakteriyel translokasyon; mukozal hasar; obstrüksiyon; probiyotik. 